\title{
Intramuscular versus Subcutaneous Administration of Iron Dextran in Suckling Piglets
}

\author{
M. SVOBODA, J. DRÁBEK \\ Clinic of Pig Diseases, Faculty of Veterinary Medicine, \\ University of Veterinary and Pharmaceutical Sciences, Brno, Czech Republic
}

Received August 15, 2006
Accepted April 26, 2007

\begin{abstract}
Svoboda M., J. Drábek: Intramuscular versus Subcutaneous Administration of Iron Dextran in Suckling Piglets. Acta Vet. Brno 2007, 76: S11-S15.

The aim of the study was to compare the development of red blood cell indices after subcutaneous versus intramuscular administration of iron dextran to suckling piglets during early postnatal period. The piglets in group I $(n=17)$ were injected subcutaneously (into groin) with $200 \mathrm{mg} \mathrm{Fe}{ }^{3+}$ as iron dextran on day 3 of life. In group II $(n=16)$, the piglets received intramuscular injection (into gluteal muscles) of $200 \mathrm{mg} \mathrm{Fe}^{3+}$ as iron dextran on day 3 of life. In group III $(n=10)$, the piglets did not receive any iron till the age of 3 days. The blood was taken and analyzed (Hb, PCV, RBC, MCV, MCH, MCHC, Fe) on days 3, 7, 14, 21, 28 and 35. Haematological indices of piglets in group III were characteristic for hypochromic anaemia. Anaemia in group III had a detrimental effect on the growth rate of piglets. The development of red blood cell indices and iron concentration in blood plasma in subcutaneously treated piglets did not differ significantly from that of intramuscularlytreated group. Both treatments prevented development of anaemia.
\end{abstract}

Haemoglobin, packed cell volume, anaemia, neonatal

Administration of iron to suckling piglets is a routine practice in swine production. The piglet is born with a limited reserve of iron (ca $50 \mathrm{mg}$ ) (Venn et al. 1947), and the sow's milk is not a sufficient source of iron for piglets. From the sow's milk, the piglets can receive 1-2 mg Fe daily (Czapó 1995). However the daily requirement of piglets for adequate haemoglobin formation and growth is $7-10 \mathrm{mg}$ of iron per day (Kleinbeck and McGlone 1999). Therefore, without any additional iron administration the piglets develop anaemia within 10-14 days after birth (Egeli et al. 1998; Zimmernann 1995).

The most common method is intramuscular injection of $200 \mathrm{mg} \mathrm{Fe}^{3+}$ in the form of iron dextran, although this method has been associated with some side effects. Firstly, Süveges and Glávits (1976) and Kolb and Hoffman (1989) described cases of acute toxicosis following iron dextran injection in antioxidant deficient piglets. Secondly, intramuscular injection of iron dextran can lead to myopathy in piglets deficient in vitamin E (Patterson et al. 1969; Chu et al. 1984; Kolb and Hoffman 1989). It has been suggested that free iron released from iron dextran activates the formation of free radicals, initiating lipid peroxidation leading to polymyositis and rhabdomyolysis (Foulkes et al. 1991). Thirdly, intramuscular injection into gluteal muscles can cause damage to nervus fibularis and nervus tibialis resulting in transient lameness of piglets (Heinritzi and Plonait 1997).

The subcutaneous administration of iron dextran into the groin would prevent the two latter complications. Surprisingly, the producers of iron dextran preparations recommend only i.m. administration. The choice of injection technique seems to be governed more by tradition than facts, since an extensive search of the literature revealed little published data concerning the merits of either technique. We therefore decided to compare the efficiency of the two routes of administration.

Address for correspondence:

MVDr. Martin Svoboda, Ph.D.

University of Veterinary and Pharmaceutical Sciences

Palackého 1-3, 61242 Brno

Czech Republic

Phone: +420541562433

E-mail: svobodama@vfu.cz

http://www.vfu.cz/acta-vet/actavet.htm 


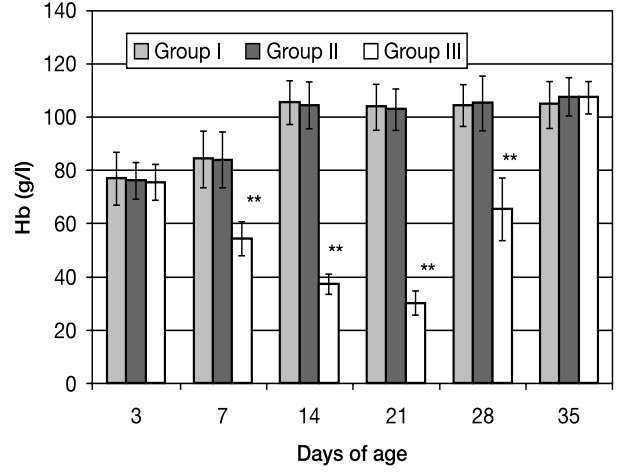

Fig 1. Haemoglobin concentration

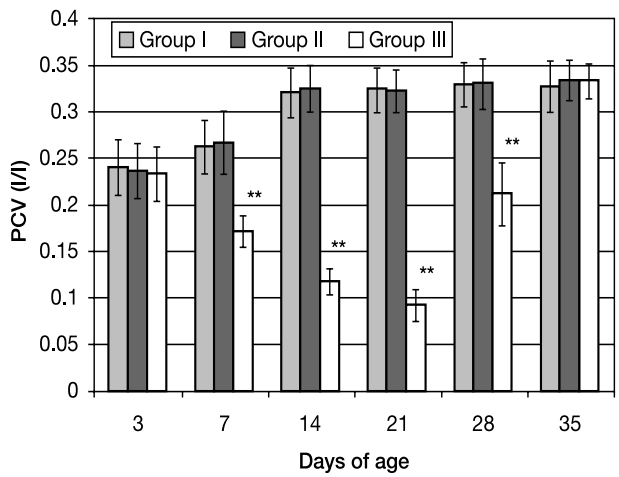

Fig. 2. Packed cell volume

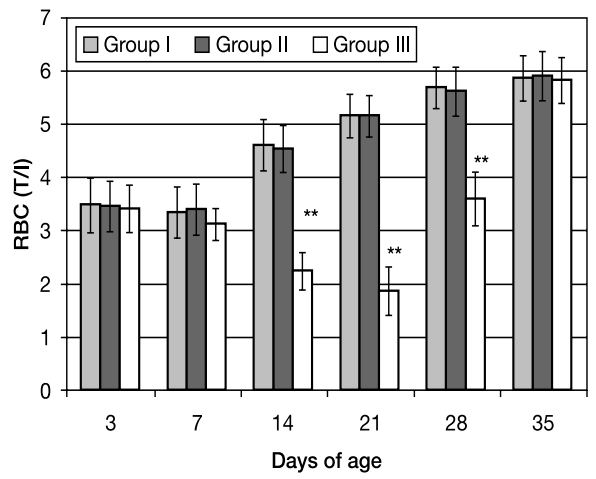

Fig. 3. Red blood cell count

\section{Materials and Methods}

Experimental design

A total of 43 piglets were used in the study. They were divided into 3 groups using split litters, i.e. each litter was divided into three different groups. The creep feed (Seltek, Tekro s.r.o. Praha, iron content 238 $\mathrm{mg} / \mathrm{kg} \mathrm{Fe}$ ) was offered to piglets from day 7 to day 35 . They were weaned at the age of 28 days. Animals in group $\mathrm{I}(\mathrm{n}=17)$ received subcutaneous injection of $200 \mathrm{mg} \mathrm{Fe}^{3+}$ as iron dextran into groin on day 3 of life. In group II $(n=16)$ the piglets were i.m. injected into gluteal muscles with $200 \mathrm{mg} \mathrm{Fe}^{3+}$ in the form of iron dextran at the age of 3 days. The piglets in group III $(n=10)$ did not receive any iron till the age of 21 days. On day 21, they were treated with iron dextran ( $200 \mathrm{mg} \mathrm{Fe}^{3+}$, i.m.).

Blood sampling

Blood was collected from vena cava cranialis of the piglets on days $3,7,14,21,28$ and 35 . The EDTA (ethylenediaminetetraacetic acid) was used as anticoagulant for the haematological examination. Heparin was used as anticoagulant for determination of iron concentration in blood plasma. The piglets were weighed at the age of $3,7,14,21,28$ and 35 days.

Haematological analysis

Haematological examination included: haemoglobin concentration $(\mathrm{Hb})$, packed cell volume (PCV), red blood cell count (RBC), mean corpuscular volume (MCV), mean corpuscular haemoglobin (MCH) and mean corpuscular haemoglobin concentration (MCHC). These indices were determined by haematological analyzer Celtac Alfa (Nihon Kohden).

\section{Iron concentration}

Iron concentration in blood plasma $(\mathrm{Fe})$ was determined photometrically measuring iron complex with ferrozin (Iron liquid 917, Roche Diagnostic, Manheim, Germany).

\section{Statistical analyses}

The results were evaluated statistically by Kruskal Wallis ANOVA test. The results are presented as mean values and standard deviations of each index in Figs $1-5$. Values with $* p<0.05,{ }^{* *} p<0.01$ express significant differences among groups.

\section{Results}

Development of haematological indices

No differences in haemoglobin concentration $(\mathrm{Hb})$ and iron concentration in blood plasma (Fe) between group I (s.c.) and group II (i.m.) were found in any period of the trial. At the age of 7 days, $23.5 \%$ of piglets in group I had $\mathrm{Hb}$ below $80 \mathrm{~g} / \mathrm{l}$ (anaemic limit). In group II, Hb values below $80 \mathrm{~g} / \mathrm{l}$ were found in $18.7 \%$ of 7 days old piglets. From day 7 to day $14 \mathrm{Hb}$ values in groups I and II increased significantly and no piglets become anaemic $(\mathrm{Hb}<80 \mathrm{~g} / \mathrm{l})$ in any remaining period of the trial. From day 3 to day 7, Fe in groups I and II increased significantly and it was decreasing from day 7 till the weaning (day 28). No differences in Fe between groups 
I and II were found during the trial. No differences in $\mathrm{MCV}, \mathrm{MCH}$ and $\mathrm{MCHC}$ were found between the groups I and II during the trial.

In group III, starting from day $7, \mathrm{Hb}$, $\mathrm{PCV}, \mathrm{MCV}, \mathrm{MCH}$ and iron concentration in blood plasma $(\mathrm{Fe})$ were found to be significantly lower than in groups I and II. After application of iron on day $21, \mathrm{Hb}$ and $\mathrm{Fe}$ in group III increased significantly.

\section{Development of body weight}

No differences in body weight were found between the groups I and II during the trial. The iron deficiency in group III resulted in significantly lower body weights compared to iron dextran treated groups.

\section{Discussion}

In order to discuss the merits of either technique, it is important to understand the mechanism of action of iron dextran. Iron dextran belongs to iron complexes of the robust and stable type with a molecular mass of 100000 daltons and more. These complexes are composed of a polynuclear iron (III) hydroxid complexed with dextran (polyisomaltose) or with dextrin (polymaltose) (Geisser 1999).

Because of its high molecular size, the iron dextran is not directly absorbed from the site of injection into the blood stream, but enters the lymphatics (Thorén-Tolling 1977, Kolb et al. 1992). Consequently 3-4 hours after deep intramuscular injection into gluteal muscles the iron content of inguinal and iliac lymph nodes is already increased (Kolb et al. 1992). The iron complex is transported via the lymphatics to body lymph nodes and further to the general circulatory system (Thorén-Tolling 1977). The iron dextran is taken from plasma by macrophages of RES (reticuloendothelial system), the iron is split off and partially reenters plasma, from where it reaches the marrow as transferrin for haemoglobin synthesis (Kolb et al. 1992).

A study concerning the rate of iron dextran absorption from injection site after i.m. injection showed that 7 days were necessary for almost complete absorption of administered dose (150 mg Fe as iron dextran). Information concerning the rate of absorption after s. c. administration is missing. The works of Miller et al. (1967) and Kolb et al. (1992) show that the iron dextran is absorbed considerably more slowly from adipose tissue.

The importance of the site of injection was demonstrated in vaccination experiments. Since the way of absorption of injected vaccines from injection site is similar to that of iron dextran (i.e., transport of high molecular complex via lymphatics), we present here following examples.

Injecting a vaccine into a layer of subcutaneous fat may result in slow mobilization and processing of antigen and in vaccination failure - for example in rabies and influenza vaccines (Groswasser et al. 1997). Compared with intramuscular injection, subcutaneous injection of hepatitis B vaccine leads to significantly lower seroconversion rates and more 
rapid decay of antibody response (Poland et al. 1997). This is in agreement with Michaels and Poole (1970) who demonstrated that adipose tissue, having much poorer drainage channels, retains injected material for much longer. Therefore the antigen takes longer to reach the circulation after being deposited in fat, leading to a delay in processing by macrophages (Seale and Zuckerman 2001).

The rapidity of iron dextran processing is an important factor for development of erythrocyte profile in early postnatal period of life of piglets. It has been demonstrated that after i.m. administration of iron dextran, certain percentage of piglets develop anaemia at the age of 7 days with values of $\mathrm{Hb}$ being below $80 \mathrm{~g} / 1$ (Lemacher and Bostedt 1995; Iben 1998). This can be explained by delayed availability of iron for haemoglobin synthesis. We suggest that further delay in iron dextran processing would cause more pronounced and longer anaemia in this life period of piglets. In our study, $23.5 \%$ of piglets in subcutaneously treated group had $\mathrm{Hb}$ below $80 \mathrm{~g} / 1$ at the age of 7 days. In intramuscularly treated group $\mathrm{Hb}$ below $80 \mathrm{~g} / \mathrm{l}$ was found in $18.7 \%$ of piglets. No differences in mean values of haematological indices between i.m. and s.c. treated piglets were found at the age of 7 days.

The subcutaneous administration of iron dextran has been employed in studies of Behrens and Lauprecht (1963) and Egeli et al. (1998). Behrens and Lauprecht (1963) found comparable growth intensity between i.m. and s.c. treated piglets, although haematological analysis was not included in the study. More recently Egeli et al. (1998) evaluated efficiency of oral administration of iron chelates in comparison with s.c. injection of iron dextran. They found good efficiency of s.c. injected iron dextran, however, comparison with i.m. technique was not included in the study.

The development of haematological parameters in group III was as expected. The piglets developed hypochromic anaemia. The piglets were not injected with iron till the age of 21 days to be certain of development of anaemia. At the age of 21 days, the piglets were injected with iron to avoid further impaired welfare. The iron deficiency in group III resulted in significantly lower body weights compared to iron dextran treated groups. The body weights remained lower till the end of the trial. The detrimental effect of iron deficiency has been documented in several studies (Egeli et al. 1998; Svoboda and Drábek 2002).

In our study, we found comparable efficiency of s.c. injection of iron dextran to that of i.m. administration in all periods of the trial. We suggest that this could be explained by relatively small amount of subcutaneous fat in 3-day-old piglets and by the proximity of the injection site (groin) to inguinal and iliac lymph nodes.

We conclude that subcutaneous injection of iron dextran into the groin represents a suitable method for iron administration in piglets.

\section{Intramuskulární versus subkutánní aplikace dextranu železa u sajících selat}

Cílem práce bylo porovnat vývoj ukazatelů červeného krevního obrazu po subkutánní versus intramuskulární aplikaci dextranu železa u sajících selat v časném postnatálním období. Selatům ve skupině I $(n=17)$ bylo ve věku 3 dnů aplikováno subkutánně (do předkolenní řasy) $200 \mathrm{mg} \mathrm{Fe}^{3+}$ ve formě dextranu železa. Ve skupině II $(\mathrm{n}=16)$ bylo 3denním selatům aplikováno intramuskulárně (do gluteální svaloviny) $200 \mathrm{mg} \mathrm{Fe} \mathrm{Fe}^{3+}$ ve formě dextranu železa. Selatům ve skupině III $(\mathrm{n}=10)$ nebylo aplikováno žádné železo do věku 21 dní.Vzorky krve byly odebrány a analyzovány (Hb, PCV, RBC, MCV, MCH, $\mathrm{MCHC}, \mathrm{Fe}$ ) ve věku 3, 7, 14, 21, 28 a 35 dnů. Hematologické parametry ve skupině III byly charakteristické pro hypochromní anémii. Anémie ve skupině III měla negativní vliv na intenzitu růstu. Vývoj ukazatelů červeného krevního obrazu a koncentrace železa v krevní plazmě ve skupině selat se subkutánní aplikací se významně nelišil od intramuskulárně ošetřené skupiny. Obě metody zabránily vzniku anémie u selat. 


\section{Acknowledgements}

The study was supported by the project MSM 6215712403.

\section{References}

BEHRENS H, LAUPRECHT E 1963: Studies on body weight development in piglets following intramuscular, subcutaneous and itra-abdominal injections of iron dextrin-cyanide and Myofer-100. Dtsch Tierarztl Wochenschr 70: 677-678

CHU JY, KANJANANGGULPAN P, CHOU AC, DE MELLO DE, FITCH CD 1984: Iron is sequestered as ferritin in macrophages in skeletal muscle of vitamin E-deficient rabbits. Pediatr Res 18: 1012-1016

CSAPÓ JE 1995: Proteins, fats, vitamins and mineral concentration in porcine colostrum and milk from parturion to 60 days. Int Dair J 6: 881-902

EGELI AK, FRAMSTAD T 1998: Evaluation of the efficacy of perorally administered glutamic acid-chelated iron and iron-dextran injected subcutaneously in Duroc and Norwegian Landrace piglets. Zentrabl Veterinarmed A 45: 53-61

EGELI AK, FRAMSTAD T, MORBERG H 1998: Clinical biochemistry, haematology and body weight in piglets. Acta Vet Scand 39: 381-393

GEISSER P, BAER M, SCHAUB E. 1992: Structure / histotoxicity relationship of parenteral iron preparations. Arzneimittelforschung 42: 1439-1452

FOULKES WD, SEWRY C, CALAM J, HODGSON HJ 1991: Rhabdomyolysis after intramuscular iron-dextran in malabsorption. Ann Rheum Dis 50: 184-186

GROSSWASSER J, KAHN A, BOUCHE B, HANQUINET S, PERLMUTER N, HESSEL L 1997: Needle length and injection technique for efficient intramuscular vaccine delivery in infants and children evaluated through an ultrasonographic determination of subcutaneous and muscle layer thickness. Pediatrics 100: 400-403

HEINRITZI K, PLONAIT H 1997: Blutkrankheiten. In Lehrbuch der Scheinekrankheiten, $2^{\text {nd }}$ ed. H Plonait, K. Bickhardt, Parey Buchverlag Berlin, p.190

IBEN B 1998: Bedeutung der peroralen Eisengabe bei Ferkeln in den ersten Lebensstunden. Tierärztl Prax 26: (G), 36-39

KLEINBECK S, MCGLONE J 1999: Intensive indoor versus outdoor production systems: Genotype and supplemental iron effects on blood haemoglobin and selected immune measures in young pigs. J Anim Sci 77: 2384-2390

KOLB E, HOFFMAN U 1989: Zur Frage der zweckmässigen Form der Anwendung von Fe-dextran, seiner Verwertung sowie des Mechanismus einer möglichen Schädigung der Ferkel. Mh Vet Med 44: 497-501

KOLB E, HOFFMAN U, NESTLER K 1992: Untersuchungen über den Gehalt an Eisen, Kupfer und Zink in verschiedenen Geweben (Magen-Darm-Kanal, Lymphknoten, Muskulatur, Herz, Leber, Milz, Niere, Pankreas, Knochenmark) bei neugeborenen Ferkeln nach oraler und intramuskulärer Verabreichung von Fe-Dextran. Mh Vet Med 47: 271-278

LEMACHER S, BOSTEDT H 1995: Entwicklung der Eisenversorgung von Saugferkeln bei unterschiedlicher Eisensupplementierung unter Beruecksichtigung der Haltungsbedingungen. Tierärztl Prax 23: 457-464

MICHAELS L, POOLE RW 1970: Injection granuloma of the buttock. Can Med Ass J 102: 626-628

MILLER ER, ULLREY DE, BRENT BE, MERKEL RA, BRADLEY BL, HOEFER JA 1967: Effects of age of pig and form of parenteral iron upon tissue iron concentration and ham discoloration at slaughter. J A V M A 150: $735-741$

PATTERSON DS, ALLEN WM, BERRETT S, SWEASEY D, THURLEY DC, DONE JT 1969: A biochemical study of the pathogenesis of iron-induced myodegeneration of piglets. Zentralbl Veterinarmed A 16: 199-214

POLAND GA, BORRUD A, JACOBSON RM, MCDERMOTT K, WOLLAN PC, BRAKKE D 1997: Determination of deltoid fat thickness: implication for needle length in adult immunization. J A M A 277: 1709-1711

SEALE JRC, ZUCKERMAN JN 2001: Importance of injecting vaccines into muscle. B M J 322: 364

SLADIC-SIMIC D, CVETKOVIC M 1978: Iron resorption and iron store in piglets after i.m. injection of ${ }^{59} \mathrm{Fe}-$ iron dextran. Zbl Vet Med A, 25, 680

SÜVEGES T, GLÁVITS R 1976: Piglet losses due to parenteral application of iron-dextran preparations. Acta Vet Aced Sci Hung 26: 257-262

SVOBODA M DRÁBEK J. 2002: Effect of administration of $\mathrm{Fe}^{2+}$-fumarate on erythrocyte profile and growth rate of suckling piglets. Acta Vet Brno 71: 217-222.

THORÉN-TOLLING K, JÖNSSON L 1977: Cellular distribution of orally and i.m. administered iron dextran in newborn piglets. Can J Comp Med 41: 318

VENN JAJ, MCCANCE RA, WIDDOWSON EM 1947: Iron metabolism in piglet anemia. J Comp Pat 57: 314-325

ZIMMERMANN,W 1995: Auswirkungen diverser Anämieprophylaxeformen auf die Blutparameter der Saugferkel. Dtsch tierärztl Wschr 102: 32-38 